\title{
Calcium- and hormone-driven regulation of secondary metabolism and cell wall enzymes in grape berry cells
}

\author{
Viviana Martins ${ }^{\mathrm{a}, \mathrm{b}, *}$, Ana Garcia ${ }^{\mathrm{a}}$, Cátia Costa ${ }^{\mathrm{a}}$, Mariana Sottomayor ${ }^{\mathrm{c}, \mathrm{d}}$, Hernâni Gerós ${ }^{\mathrm{a}, \mathrm{b}, \mathrm{e}}$

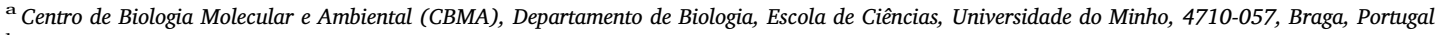

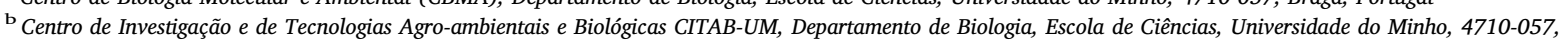 \\ Braga, Portugal

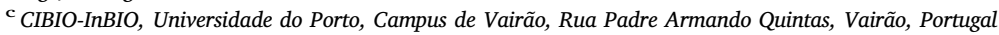 \\ ' Departamento de Biologia, Faculdade de Ciências, Universidade do Porto, Porto, Portugal \\ e Centro de Engenharia Biológica (CEB), Universidade do Minho, 4710-057, Braga, Portugal
}

\section{A R T I C L E I N F O}

\section{Keywords:}

Abscisic acid

Anthocyanin

Cell wall metabolism

Methyl jasmonate

UFGT

Vitis vinifera

\begin{abstract}
A B S T R A C T
The efficacy of calcium sprays for improving fleshy fruit resistance to abiotic/biotic stress and enhancement of fruit shelf life has increasingly been explored. However, because calcium is a powerful secondary messenger in many signaling pathways, including those driven by abscisic acid (ABA) and jasmonates, it may interfere with the biosynthesis of specialized metabolites highly important for fruit and wine quality, such as phenolic compounds. In this study, a combination of biochemical and molecular biology approaches were applied to grape cell cultures and detached grape berries, in order to investigate the effect of calcium in the modulation of enzymes involved in the biosynthesis of phenolic compounds and in cell wall organization. Concentrations up to $10 \mathrm{mM}$ $\mathrm{CaCl}_{2}$ did not affect cell growth, size or viability, but triggered modifications in total phenolics content, particularly in anthocyanin levels in grape cell suspensions. The effects of calcium applied alone or in combination with ABA or methyl jasmonate (MeJA) were visible in several branches of specialized metabolic pathways, confirming that the calcium-hormone interplay regulates the expression of phenylalanine ammonia lyase (PAL), stilbene synthase (STS), dihydroflavonol reductase (DFR) and UDP-glucose:flavonoid 3-O-glucosyltransferase (UFGT). The activity of PAL and UFGT enzymes was also specifically modulated by calcium, ABA and MeJA. These results closely correlated to the modifications observed in the expression of $V v A M 1$ and $V v A B C C 1$ encoding vacuolar anthocyanin transporters. Modulation of the expression and activity of pectin methyl esterases (PME) and polygalacturonases (PG) by calcium was also evident, confirming an important role of calcium in cell wall organization via the regulation of enzyme activity, besides its well-known role in the formation of cross links between pectin molecules. Overall, this study uncovers important biochemical mechanisms induced by calcium and stress hormones on grape berries, and highlights the need to consider the consequences of calcium treatments and stress for fruit quality.
\end{abstract}

\section{Introduction}

Achieving an optimal balance betweenproductivity and fruit quality is a major aspiration in viticulture that is particularly challenging in the context of ongoing climate changes. Steady rains before harvest cause fruit swelling, diluting the flavors and causing cracking of the skin, making fruits more prone to spoilage and infection by microorganisms, both before and after harvest. This is particularly critical in cultivars with thin skin, resulting in limited storability and lower incomes. Because the use of fungicides is increasingly raising concerns for the environment and human health (Taylor, 1993; Martins et al., 2014a, 2014b, 2015), the exploitation of alternative environmentally friendly and sustainable treatments is of utmost importance in viticulture.

With a central role in maintaining cell turgor, cell wall resistance,

\footnotetext{
Abbreviations: ABA, abscisic acid; CHS, chalcone synthase; DFR, dihydroflavonol reductase; FDA, fluorescein diacetate; GAPDH, glyceraldehyde-3-phosphate de-

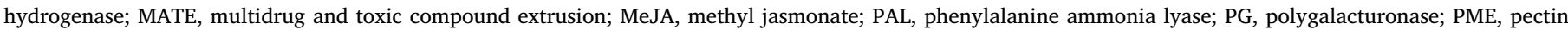
methylesterase; STS, stilbene synthase; UFGT, UDP-glucose:flavonoid 3-O-glucosyltransferase

* Corresponding author at: Centro de Biologia Molecular e Ambiental (CBMA), Departamento de Biologia, Escola de Ciências, Universidade do Minho, 4710-057, Braga, Portugal.

E-mail address: vmartins@bio.uminho.pt (V. Martins).
} 
and fruit firmness (Hocking et al., 2016), calcium has been used efficiently in post-harvest food supplements for extending fruit shelf-life (Hopkirk et al., 1990; Martín-Diana et al., 2007), and its efficacy for improving fruit firmness when applied at pre-harvest stages has been tested in a few crops, including papaya, sweet cherry, apple, and table grapes (Siddiqui and Bangerth, 1995; Bonomelli and Ruiz, 2010; Wójcik et al., 2013; Madani et al., 2016). The mechanisms of calcium incorporation in grape berry cells are so far largely uncharacterized. Being phloem immobile, calcium is taken up by fruits through the xylem, thus depending greatly upon transpiration rates (Martins et al., 2012). Besides the cell wall, the grape berry vacuole constitutes a major sink for calcium, and several transporters including ACA- and CAX-type proteins account for its movement to and from the cytosol (Martins et al., 2017). These movements underlie calcium signatures involved in signaling responses to specific stresses and cell processes (Dodd et al., 2010). Importantly, calcium is known to act as secondary signal messenger in phytohormonal pathways responding to abiotic and biotic stresses, such as the ABA response to drought stress and the onset of anti-herbivore responses mediated by jasmonates (Dodd et al., 2010; Fortes et al., 2015). Therefore, given the interplay of ABA and jasmonates observed during grape berry ripening, the direct or indirect effects of calcium on other fruit properties such as color and aroma bouquet cannot be disregarded, particularly in grape berry where color quality and aroma bouquet are determinant for commercial value (Conde et al., 2007).

Moreover, besides mediating the cross-linking of cell wall polysaccharides and having structural roles in the cell wall and membranes, calcium acts as a counter-cation for both organic and inorganic anions in the vacuole of grape berry, further meddling in the composition of key solutes for grape quality (Martins et al., 2012).

Hence, the present study firstly aimed at understanding the effect of calcium on basic features of grape cell dynamics including growth rates, size and viability, and secondly, its effects on the pathways leading to the formation of phenolic compounds important for grape berry quality, with special emphasis on anthocyanin biosynthesis and accumulation, and on the regulation of cell wall enzymes involved in pectin organization. As these processes are tightly regulated by hormones during fruit ripening and stress responses (Conde et al., 2007), the combined effects of calcium and ABA or methyl jasmonate (MeJA) were also explored, both on grape cell cultures and intact detached berries.

\section{Material and methods}

\subsection{Growth, size and viability of grape suspension cells}

Cells of V. vinifera L. $c v$. Gamay Fréaux var. Teinturier, gently provided by Prof. Serge Delrot (University of Bordeaux, France), were grown in liquid mineral medium supplemented with $58 \mathrm{mM}$ sucrose, according to Decendit and Merillon (1996), on a rotatory shaker at 100 r.p.m., under an $8 \mathrm{~h}$ dark $/ 16 \mathrm{~h}$ light $\left(200 \mu \mathrm{mol}\right.$ photons $\left.\mathrm{m}^{-2} \mathrm{~s}^{-1}\right)$ photoperiod, at $24^{\circ} \mathrm{C}$. Cells were subcultured weekly by transferring $15 \mathrm{~mL}$ aliquots into $30 \mathrm{~mL}$ of fresh medium. To study the effect of calcium on cell growth, size and viability, cells were subcultured in medium supplemented with increasing concentrations of $\mathrm{CaCl}_{2}: 1 \mathrm{mM}$ (basal levels), 5, 10, 50 and $100 \mathrm{mM}$. Three biological replicates were performed per $\mathrm{CaCl}_{2}$ concentration. Cell growth was determined through dry-weight measurements: aliquots $(1-3 \mathrm{~mL})$ were filtered through pre-weighed GF/C filters (Whatman), washed with deionized water and weighed after $24 \mathrm{~h}$ at $80^{\circ} \mathrm{C}$. Ten days after subculture, cell viability was tested with the fluorescent dye fluorescein diacetate (FDA, Sigma), in a Leica Microsystems DM-5000B epifluorescence microscope with appropriate filter settings. Images were acquired with a Leica DCF350FX digital camera and processed with LAS AF Leica Microsystems software. Cell size was estimated by measuring the average cell diameter.

\subsection{Induction of secondary metabolism in cell suspensions and treatments}

To study the effect of calcium on secondary metabolism and its possible interactions with hormones associated to fruit ripening and stress response, cells were transferred to induction medium that stimulates secondary metabolism pathways in this cell line, as described by Larronde et al. (1998), and grown for 3 d. For gene expression and enzyme activity studies, filter sterilized stock solutions were added to the cultures at day 3, to achieve the following final concentrations: $10 \mathrm{mM} \mathrm{CaCl}_{2}, 20 \mu \mathrm{M} \mathrm{ABA}, 20 \mu \mathrm{M}$ MeJA, $10 \mathrm{mM} \mathrm{CaCl}_{2}+20 \mu \mathrm{M} \mathrm{ABA}$, or $10 \mathrm{mM} \mathrm{CaCl}_{2}+20 \mu \mathrm{M}$ MeJA. The selected ABA and MeJA concentrations were optimized following previous studies (Noronha et al., 2015). Non-treated cells were used as control. Three biological replicates were performed per treatment. After $12 \mathrm{~h}$, cells were collected by vacuum filtration, ground in liquid $\mathrm{N}$ and stored at $-80^{\circ} \mathrm{C}$ for further experiments. For assessments of the effect of calcium/hormones in metabolite levels, cells were grown for $4 \mathrm{~d}$ in induction medium supplemented at day 1 with the concentrations of calcium and hormones detailed above.

\subsection{Short-term culture of intact detached grape berries and treatments}

Berries cv. Vinhão were collected at veraison stage (Coombe, 1995) from 3-year-old grapevines located in the DOC region of Vinhos Verdes, and cultivated in vitro as previously described (Dai et al., 2014), with minor modifications. Briefly, berries with a pedicel $\sim 5 \mathrm{~mm}$ long were excised from clusters, submerged in $70 \%$ ethanol for $10 \mathrm{~s}$ and then in a $1 \% \mathrm{NaClO}$ solution for $2 \mathrm{~min}$. After rinsing with deionized water, the berries pedicel was quickly dipped into liquid mineral medium supplemented with the same treatments used in cell cultures, on 96-well plates, and berries were incubated at the same temperature and light conditions described previously, for $4 \mathrm{~d}$. Each treatment was performed in eight berries. Fruits were then ground in liquid $\mathrm{N}$ and stored at $-80{ }^{\circ} \mathrm{C}$ for further experiments.

\subsection{Quantification of total phenolics and anthocyanins}

Total phenolics were extracted from $200 \mathrm{mg}$ f.w. of cells or grape berry tissue with $1 \mathrm{~mL}$ of $100 \%$ methanol, and quantified by the FolinCiocalteau colorimetry method (Waterhouse, 2002). Total anthocyanins were extracted from $200 \mathrm{mg}$ f.w. of cells or grape berry tissue with $1 \mathrm{~mL}$ of $100 \%$ acetone and quantified by the differential $\mathrm{pH}$ method (Nicoue et al., 2007). Results were expressed as mg of gallic acid per $g$ of d.w. and $\mathrm{mg}$ of anthocyanin per $\mathrm{g}$ of d.w.

\subsection{Enzyme activity assays}

Total protein extraction was performed according to the method described by Deytieux-Belleau et al. (2008), using $300 \mathrm{mg}$ f.w. and $800 \mu \mathrm{L}$ of ice-cold buffer containing $0.3 \mathrm{M}$ Tris-HCl pH 7.0, $13 \mathrm{mM}$ EDTA, $5 \mathrm{mM}$ dithiothreitol, $1 \mathrm{M} \mathrm{NaCl}, 1 \%(\mathrm{w} / \mathrm{v})$ polyvinylpyrrolidone, $20 \%(\mathrm{v} / \mathrm{v}$ ) glycerol and $1 \%$ Triton X-100. Total protein was quantified with the Bradford method (Bradford, 1976). Absorbance measurements were performed in a Shimadzu UV-1700 Spectrophotometer.

The activity of PAL was assessed as previously reported (Conde et al., 2016), with minor modifications. The reaction mixture contained $100 \mathrm{mM}$ Tris - $\mathrm{HCl} \mathrm{pH} \mathrm{8.9,} \mathrm{4.3} \mathrm{mM} \mathrm{NaCl,} 19.2 \mathrm{mM}$-phenylalanine as substrate, and $50 \mu \mathrm{L}$ of protein extract, in a final volume of $1 \mathrm{~mL}$. The production of trans-cinnamic acid was followed at $39^{\circ} \mathrm{C}$ for $15 \mathrm{~min}$ and recorded at $290 \mathrm{~nm}$. UFGT activity was determined according to the method described by Mori et al. (2005), with some modifications. The assay mixture consisted of $20 \mathrm{mM}$ sodium phosphate buffer $\mathrm{pH} 8.0,50$ $\mu \mathrm{M}$ quercetin, $0.5 \mathrm{mM}$ UDP-glucose and $50 \mu \mathrm{L}$ protein extract in a final volume of $2 \mathrm{~mL}$. The mixture was incubated at $30^{\circ} \mathrm{C}$ for $30 \mathrm{~min}$, under shaking, and the production of quercetin-3-glucoside was recorded at $350 \mathrm{~nm}$. Results were calculated using an extinction coefficient $(\varepsilon)$ for 
quercetin-3-glucoside of $21,877 \mathrm{M} \mathrm{cm}^{-1}$. The activity of PME was assayed following an adaptation of a previously described method (Hagerman and Austin, 1986). The reaction mixture contained $700 \mu \mathrm{L}$ of $0.5 \%(\mathrm{w} / \mathrm{v})$ pectin solution, $50 \mu \mathrm{L}$ of $0.01 \%(\mathrm{w} / \mathrm{v})$ bromothymol blue and $200 \mu \mathrm{L}$ of protein extract. The mixture was incubated at $25^{\circ} \mathrm{C}$ and absorbance was recorded at $620 \mathrm{~nm}$. Enzyme activity was determined using a standard curve with $\mathrm{HCl}$. PG biochemical activity was assessed according to Lohani et al. (2004). The reaction mixture contained $60 \mathrm{mM}$ sodium acetate buffer $\mathrm{pH} 4.5,20 \mathrm{mM} \mathrm{NaCl}, 1 \%$ (w/v) polygalacturonic acid and $100 \mu \mathrm{L}$ of protein extract, in a final volume of $1 \mathrm{~mL}$. The mixture was incubated at $37^{\circ} \mathrm{C}$ for $15 \mathrm{~min}$ and the reaction was stopped in a boiling water bath for $5 \mathrm{~min}$. Next, $100 \mu \mathrm{L}$ of the reaction mixture were added to $100 \mu \mathrm{L}$ of 3,5-dinitrosalicylic acid and incubated at $100^{\circ} \mathrm{C}$ for $15 \mathrm{~min}$. The formation of reducing sugars was measured at $540 \mathrm{~nm}$ and determined by interpolation with a D-glucose calibration curve.

\subsection{RNA extraction and expression studies by real-time PCR}

Total RNA was extracted from $300 \mathrm{mg}$ of ground samples following the classical method described by Reid et al. (2006) and mRNA was converted to cDNA by reverse transcription with an Omniscript ${ }^{\circ}$ RT Kit and oligo (dT) primers (Qiagen). Quantitative real-time PCR (qPCR) was performed in 96-well plates with Quantitect SYBr green ${ }^{\circ}$ Master Mix (Qiagen). Briefly, for each biological replicate $(n=3)$, qPCR reactions were performed in triplicate (technical replicates) using $10 \mu \mathrm{L}$ MasterMix, $300 \mathrm{nM}$ of each primer, $1 \mu \mathrm{L}$ of cDNA and nuclease-free water to a final volume of $20 \mu \mathrm{L}$. The following cycler conditions were used: $15 \mathrm{~min}$ at $95^{\circ} \mathrm{C}$ and 45 cycles of $15 \mathrm{~s}$ at $94^{\circ} \mathrm{C}, 30 \mathrm{~s}$ at $55^{\circ} \mathrm{C}$ and $30 \mathrm{~s}$ at $72^{\circ} \mathrm{C}$. The annealing temperature for $V v P G 1$ and $V v P G 2$ amplicons was lowered to $52^{\circ} \mathrm{C}$ according to previous reports (DeytieuxBelleau et al., 2008), and extension occurred for $1 \mathrm{~min}$. Fluorescence was measured at the end of each amplification cycle. The sequences of gene-specific primers were retrieved from previously published studies, and are detailed in supplementary table I. Gene expression was normalized to the $V v G A P D H$ reference gene (NCBI/Genbank database accession no. XM_002263109, Gainza-Cortés et al., 2012). The specificity of PCR reactions was checked through dissociation curves at the end of each qPCR reaction, by heating the amplicons from 65 to $95^{\circ} \mathrm{C}$. Data were analyzed using the CFX Manager Software (Bio-Rad laboratories, Inc.).

\subsection{Statistical analysis}

One-way ANOVA was used to statistically analyze the results in Prism $^{\circledast} 6$ (GraphPad Software, Inc.). In graphs, significant differences are marked by different letters (a, b, c, d, e).

\section{Results}

\subsection{Effect of calcium on growth, size and viability of grape cells}

As shown in Fig. 1A, the growth of suspension cells of $V$. vinifera $\mathrm{L}$. cv. Gamay Fréaux var. Teinturier was modulated by calcium in a dosedependent manner, remaining unaffected in concentrations up to $10 \mathrm{mM}$. A similar behavior was observed for cell size and viability, with higher calcium concentrations causing a significant decrease in cell diameter and a reduction in esterase activity measured by FDA staining (Fig. 1B). Therefore, subsequent studies were performed with $10 \mathrm{mM}$ calcium.

\subsection{Effect of calcium on secondary metabolism of grape cells}

Although cell growth, size and viability were not affected by the selected calcium dosage, modifications in the pigmentation of Gamay cells were clearly visible (Fig. 2A). Hence, after ruling out possible interference of the medium $\mathrm{pH}$, total phenolics and anthocyanins were quantified. As shown in Fig. 2B, the content of total phenolics was not affected by the presence of calcium alone, in comparison to control cells. Likewise, in cells treated with ABA, the addition of calcium did not affect the production of total phenolics. However, in cells treated with MeJA, which led to the production of higher levels of phenolics, calcium caused a significant reduction in the levels of these metabolites.

The effects of calcium were more pronounced in total anthocyanin content than in total phenolics, and a significant reduction was observed, particularly when cells were treated with MeJA (Fig. 2B), correlating well with the cell pigmentation profile. Overall, calcium showed a consistent tendency for an inhibitory effect of the measured pathways of secondary metabolism.

Gene expression and enzyme activity studies were then performed on key intermediates of the biosynthetic pathways of phenylpropanoids, stilbenes, flavonoids, flavonols and, specifically, anthocyanins. PAL is the enzyme that catalyzes the first step of the phenylpropanoid pathway and, therefore, is the starting point for the biosynthesis of phenolic compounds. As shown in Fig. 3A, calcium upregulated VvPAL1 when added alone and in cells treated with ABA. However, in cells treated with MeJA, which induced a strong expression of $V v P A L 1$, transcript levels decreased by $65 \%$ in the presence of calcium. Likewise, a stimulatory effect of calcium was observed when PAL enzyme activity was measured in protein extracts, and calcium also inhibited the activity of the enzyme in cells treated with MeJA. As depicted in Fig. 3B the expression of $V v C H S 3$ coding for a chalcone synthase, a key enzyme of the first step of flavonoids biosynthesis, was consistently upregulated in the presence of calcium, either when added alone or in combination with ABA or MeJA, showing a remarkable induction of 15 -fold in cells treated with both MeJA and calcium, in comparison to cells treated with MeJA only. The expression of VvSTS coding for a stilbene synthase, the first enzyme for the biosynthesis of stilbenes, was similar in control cells and ABA-treated cells, remaining unaffected by calcium, either when added alone or in combination with ABA (Fig. 3B). In MeJAtreated cells, VvSTS was significantly upregulated, but this increase in $V v S T S$ transcript levels was significantly prevented by calcium $(70 \%$ reduction). The expression of VvFLS1 encoding an isoform of the first enzyme of flavonols biosynthesis was repressed by calcium (37\%), ABA (34\%), and MeJA (93\%) (Fig. 3B), with calcium further repressing $V v F L S 1$ transcription when added in combination with ABA.

Studies were then directed towards the steps catalyzing anthocyanin biosynthesis and accumulation. As shown in Fig. 4A, calcium alone upregulated $V v D F R$ expression. The same trend was observed when cells were treated with ABA alone and MeJA alone. While calcium did not affect the expression of $V v D F R$ when cells were treated with ABA, it strongly repressed the expression of the gene when combined with MeJA. The expression of VvUFGT was also upregulated in the presence of calcium alone, as well as in cells treated with MeJA alone. Calcium did not affect the expression of VvUFGT in combination with ABA, but again sharply repressed the expression of the gene when combined with MeJA. UFGT catalyzes the limiting step towards anthocyanin biosynthesis, hence its enzyme activity was also studied in grape cell protein extracts. Surprisingly, UFGT enzyme activity was consistently inhibited in the presence of calcium (55-88\%), either added alone or in combination with ABA or MeJA, revealing that calcium may have opposite effects at the levels of transcription and protein activity regulation.

The expression of $V v A M 1$, which encodes a MATE-type protein that mediates the antiport of acylated anthocyanins with $\mathrm{H}^{+}$across the vacuole membrane (Gomez et al., 2009) is depicted in Fig. 4B. The treatment of cells with ABA or MeJA downregulated the expression of $V v A M 1$, but while calcium did not affect the expression of $V v A M 1$, neither in control cells nor in cells treated with ABA, it strongly decreased the steady-state transcript levels in cells treated with MeJA. The expression pattern of $V v A B C C 1$, encoding an ATP-binding cassette-type protein which transports glucosylated anthocyanidins into the vacuole 
A

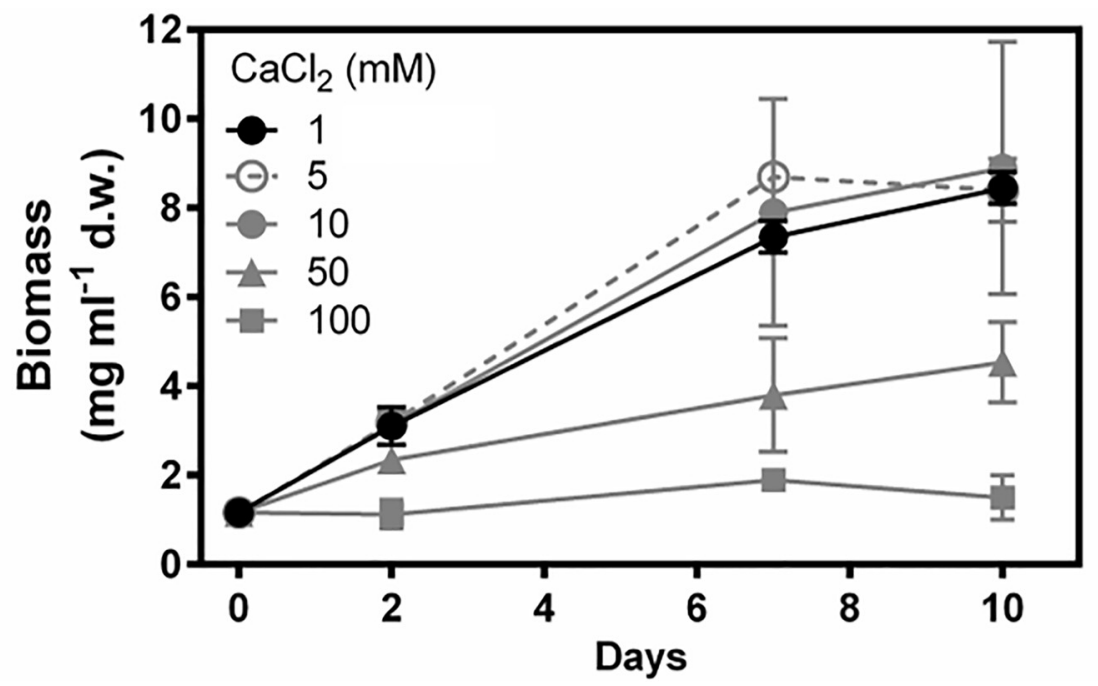

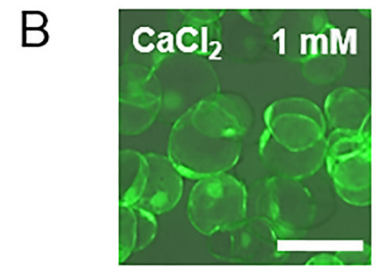

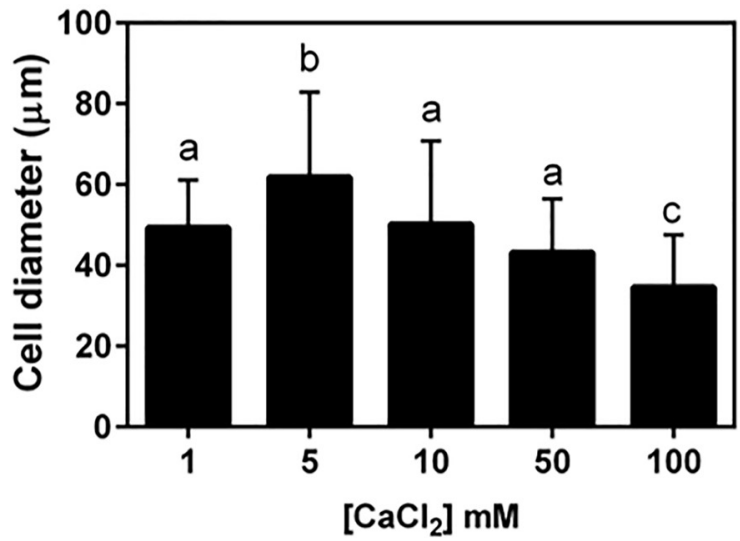

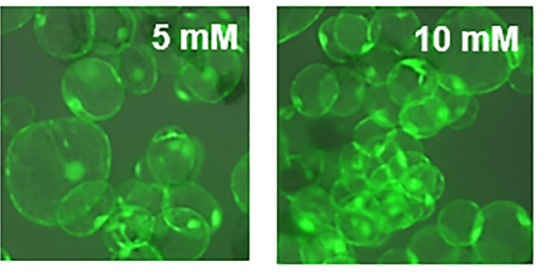
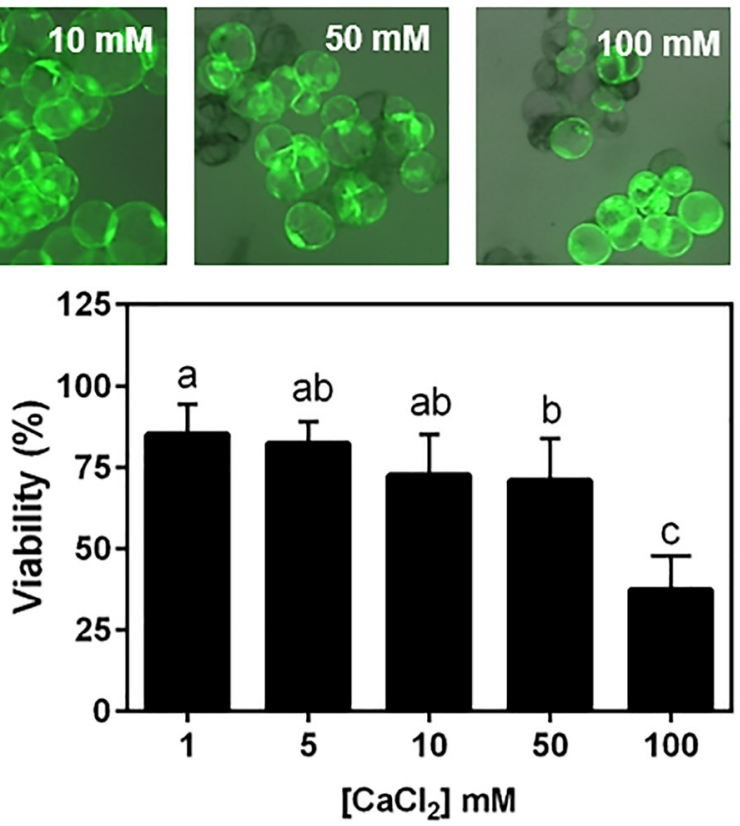

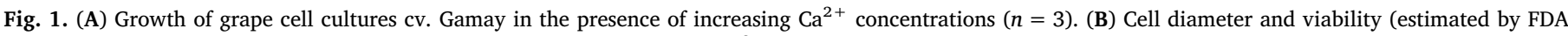

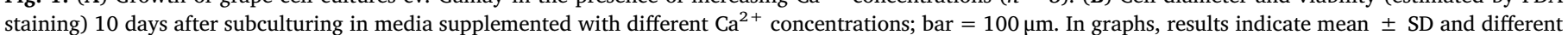
letters indicate statistically significant differences.

and is dependent on the presence of reduced glutathione -GSH (Francisco et al., 2013) is depicted in Fig. 4B. Calcium alone was able to stimulate $V v A B C C 1$ transcription, which was also induced by MeJA alone, while the treatment with ABA alone did not affect gene expression. The presence of calcium in cells treated with MeJA prevented the upregulation of gene expression observed in cells treated with MeJA alone.

3.3. Effect of calcium on the expression and activity of cell-wall enzymes involved in pectin organization in grape cells

The enzyme PME generates hydrolysable sites in pectin polysaccharides, that either become available for crosslinking with calcium, strengthening the cell wall, or become susceptible to the action of PG, that cleaves the molecules causing softening of the cell wall. As shown in Fig. 5A, treating grape cells with ABA alone did not affect the expression of $V v P M E 1$, while MeJA caused a sharp upregulation of gene expression. Calcium did not significantly affect the expression of $V \nu P M E 1$, either when applied alone or in combination in each hormone.
However, the biochemical activity of PME enzyme was inhibited by calcium in cells treated with ABA, while no differences were observed in the remaining conditions. In contrast, the inhibition of $V v P G s$ expression mediated by calcium was very consistent in all experimental conditions (Fig. 5B). Thus, the expression of $V v P G 1$, which was only measurable in cells treated with ABA, was downregulated in the presence of calcium, and the expression of $V v P G 2$ was downregulated in the presence of calcium applied in combination with ABA or MeJA. The treatment with MeJA alone decreased the steady-state levels of $V v P G 2$ transcripts in comparison to control cells, contrarily to ABA which did not affect gene expression. Accordingly, PG enzyme activity was consistently inhibited in the presence of calcium, either when added alone or in combination with ABA or MeJA.

3.4. Transcriptional reprograming in intact detached berries in response to calcium

Intact detached grape berries were incubated with $\mathrm{ABA}$ or MeJA, in the presence and in the absence of calcium, to mimic the experimental 

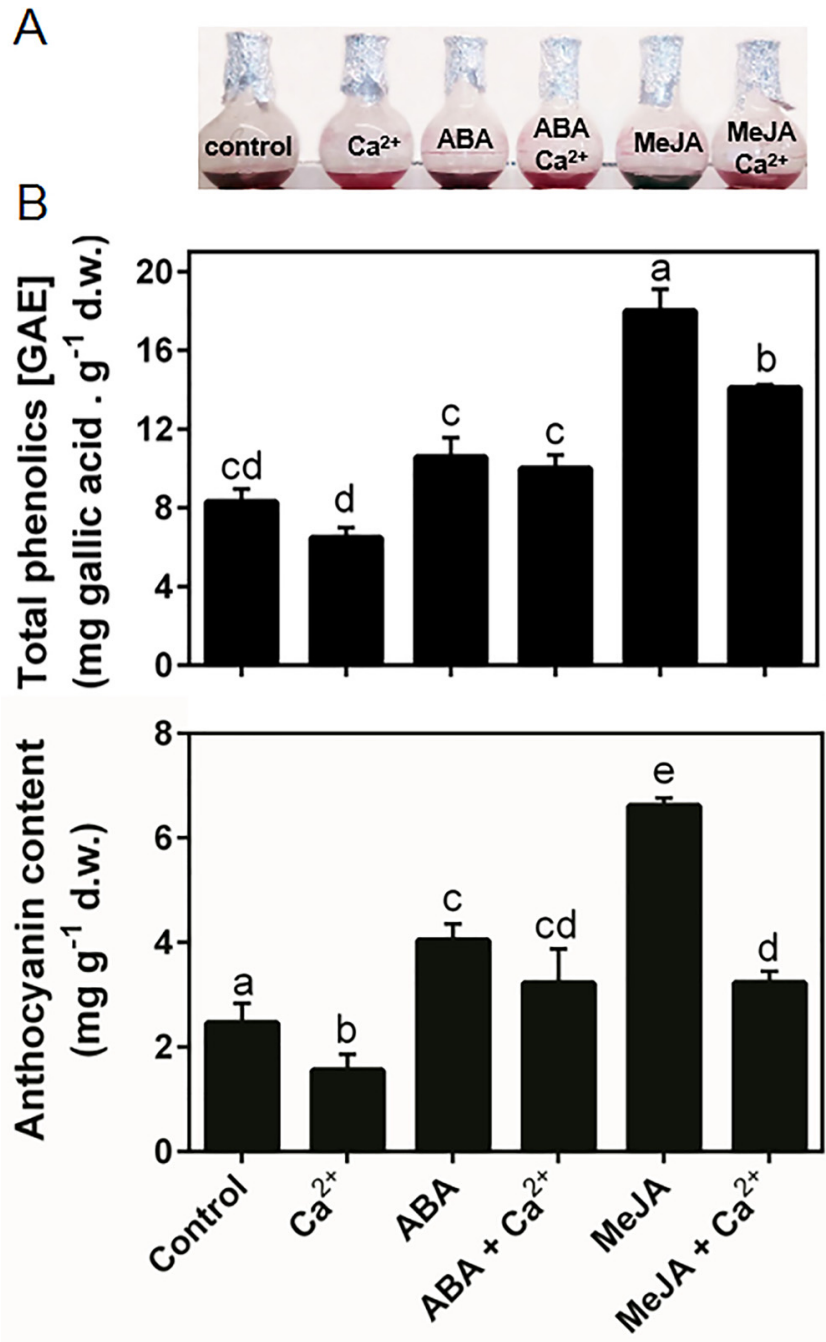

Fig. 2. (A) Pigmentation and (B) total levels of phenolics and anthocyanins in grape cells cv. Gamay $4 \mathrm{~d}$ after subculturing in media supplemented with different combinations of calcium and hormones: $\left[\mathrm{Ca}^{2+}\right]=10 \mathrm{mM},[\mathrm{ABA}]=20$ $\mu \mathrm{M}$ and $[\mathrm{MeJA}]=20 \mu \mathrm{M}$. Results indicate mean \pm SD of three biological replicates and different letters indicate statistically significant differences.

conditions used to study gene expression and enzyme activities in grape cell cultures. As shown in Fig. 6, VvPAL1 was not significantly affected by calcium treatment. However, an apparent stimulatory effect was driven by MeJA, in accordance to the effects observed in cell suspensions. VvDFR expression was highest in non-treated berries, and consistently inhibited in the remaining conditions tested, in a similar degree. The expression of $V v U F G T$ and $V v A B C C 1$ was not significantly affected by hormonal treatment, but calcium significantly downregulated VvUFGT expression in cells treated with MeJA (Fig. 6), in accordance to the pattern observed in grape cell cultures (Fig. 4). The expression of VVPME1 was upregulated in berries treated with MeJA alone, but this stimulation of gene expression was prevented by calcium (Fig. 6), in agreement with the results obtained in cell cultures. The repression of $V v P G 1$ and $V v P G 2$ mediated by calcium, which was very clear in cell cultures, was only apparent in some conditions in intact detached berries (Fig. 6). The above transcriptional reprograming occurring in intact detached berries did not promote substantial differences regarding total phenolics and total anthocyanin content (supplementary Fig. 1).

\section{Discussion}

\subsection{Calcium levels modulate grape cell growth, size and viability}

Unravelling the mechanisms of calcium incorporation in fleshy fruits is particularly important given its key role in cell wall structure and fruit firmness. Hence, high calcium levels may be beneficial to ensure maintenance of fruit health during development and extend selflife (Martín-Diana et al., 2007). However, for being such a powerful secondary messenger in many cellular processes including phytohormonal pathways (Fortes et al., 2015; Hocking et al., 2016), possible collateral effects in other determinants of fruit quality cannot be disregarded, particularly in the grape growing and winemaking industries that greatly rely upon color quality and phenolic richness. Suspension cells of $V$. vinifera L. cv. Gamay Fréaux var. Teinturier produce considerable amounts of anthocyanins, consisting of a good model to investigate calcium effects not only in basic cell parameters such as growth, but also in secondary metabolic pathways. Notwithstanding the necessary caution when extrapolating results obtained using cultured grape berry cells to tissue or whole-plant levels, the cultured berry cells offer a number of distinct advantages over plant tissues, since problems associated with bulk diffusion, tissue penetration barriers and cell heterogeneity can be avoided (Martins et al., 2012). Moreover, studies were complemented with the experimental model of intact detached berries in culture.

Initial toxicological studies showed that up to $10 \mathrm{mM}$ calcium no deleterious effects arise for cell growth, viability and size, suggesting that grape cells are able to cope with these concentrations, possibly by sequestering excess calcium in safe storages such as the vacuole, as previously suggested (Fontes et al., 2010; Martins et al., 2017). The observed inhibition of cell growth and viability and decrease in cell size at higher calcium concentrations may primarily arise from the disturbance of the osmotic potential, and deregulation of signaling processes in the cell wall, membranes and organelles (Martins et al., 2012).

\subsection{Calcium-hormone interplay regulates key enzymes involved in secondary metabolism pathways}

Calcium effects were visible from the earliest steps of secondary metabolism pathways as summarized in Fig. 7, affecting PAL gene expression and enzyme activity concordantly, depending on the presence of ABA or MeJA, suggesting a strong calcium-hormonal interplay in the regulation of this enzyme, and also of VvSTS, VvDFR, VvUFGT, VvAM1 and $V v A B C C 1$. In many cases, calcium seemed to block MeJA signaling processes by decreasing the degree of upregulation of gene expression triggered by this hormone. Given the myriad of processes in which these two signaling agents participate, it is difficult to ascertain exactly which pathways are subject to calcium interference. Nonetheless, a few previous studies have reported a strong link between calcium and MeJA signaling pathways (Hamilton et al., 2000; Pei et al., 2000; Suhita et al., 2003, 2004; Sun et al., 2006). The influx of calcium is necessary for elicitor-induced jasmonic acid synthesis and secondary metabolite accumulation (Hu et al., 2009; Wasternack and Hause, 2002). However, the direction of the effect of jasmonic acid, for instance, on $\mathrm{Ca}^{2+}$-ATPase (stimulation or suppression), depends on the tissue physiological state and the phytohormone concentration (Ladyzhenskaia and Korableva, 2008). Hence, further studies are required to fully understand the mechanisms underlying the interplay of calcium and MeJA.

In contrast to the enzymes reported above, the effects of calcium on $V v C H S 3$ stimulation and VvFLS1 downregulation did not seem to be hormone-dependent, therefore, the calcium-MeJA connection seems to be prominent only in some branches of secondary metabolism pathways.

In general, results further suggested that, upon calcium treatment, the metabolism was directed towards flavonoid biosynthesis in detriment of stilbene synthesis, by upregulation of $V v C H S 3$ and 
A
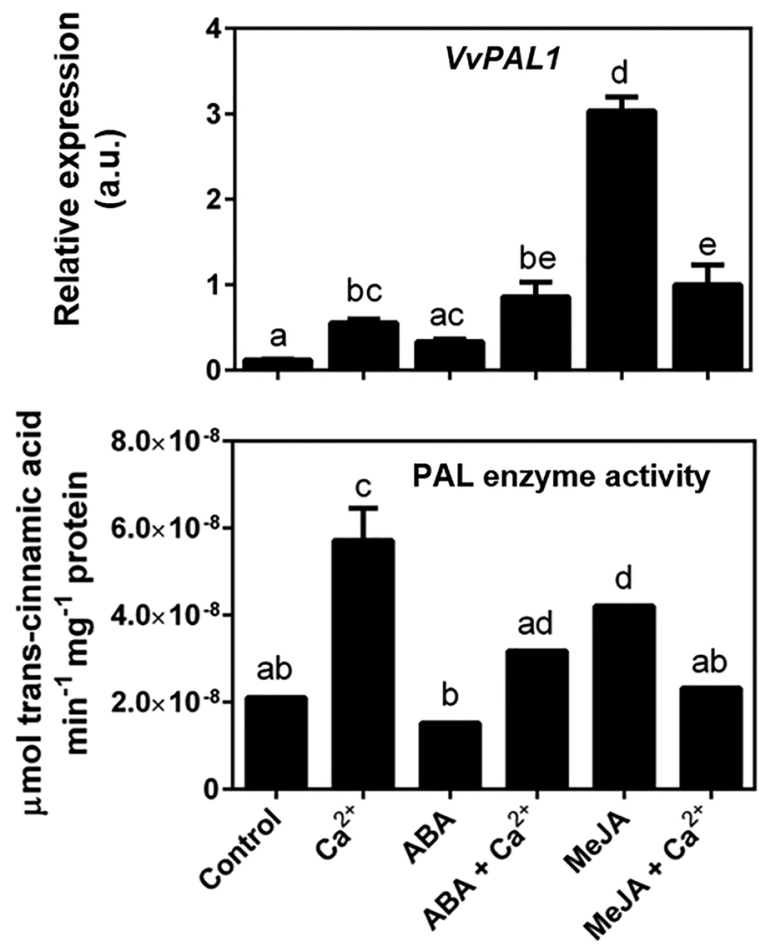

$\mathrm{B}$
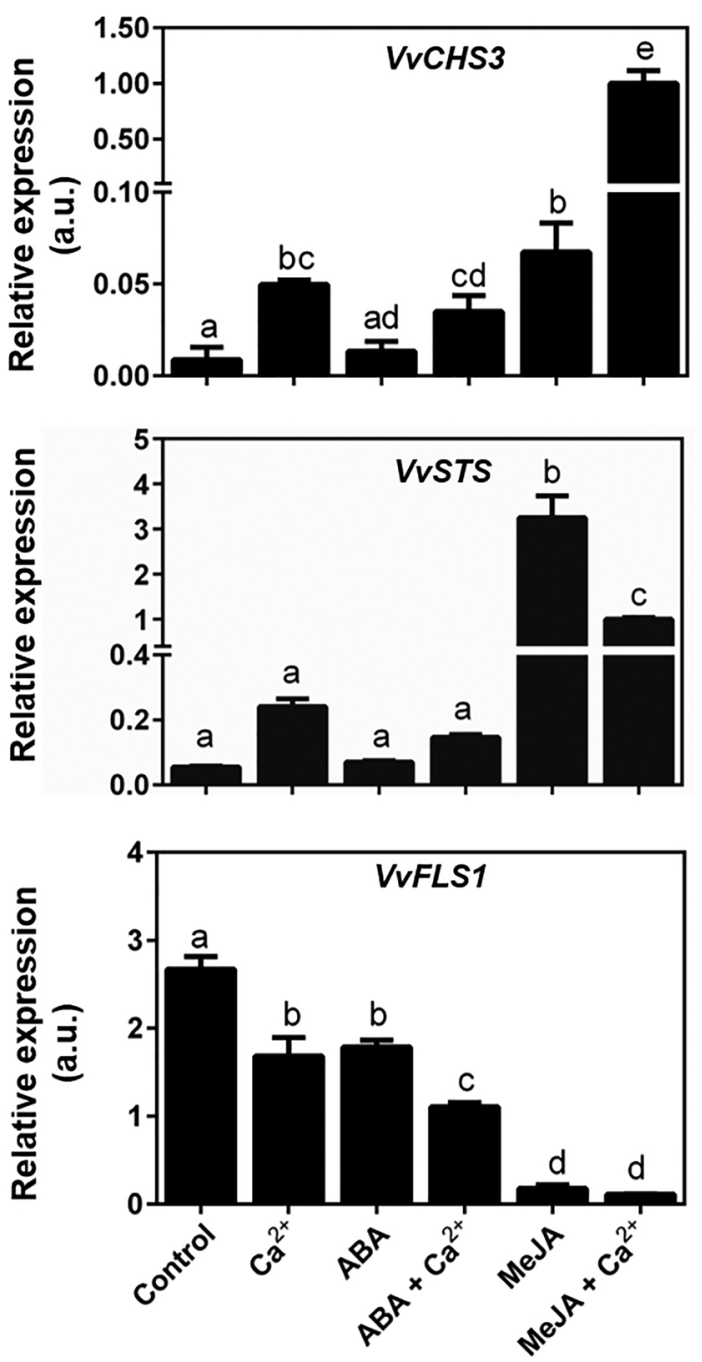

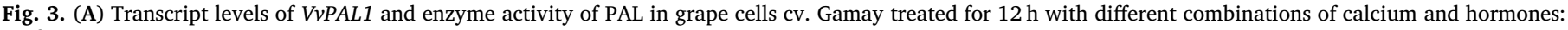

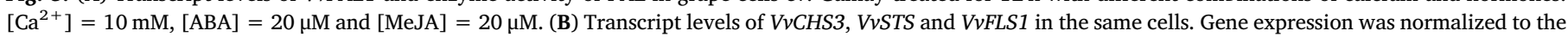

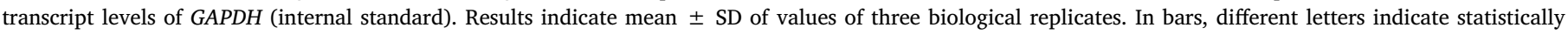
significant differences.

downregulation of VvSTS. Moreover, flavonol biosynthesis could be partially halted as suggested by VvFLS1 downregulation, probably favoring the synthesis of other flavonoids. These results highlight the intricate signaling pathways in which calcium is involved and the interplay with other signaling processes. Accordingly, recent studies demonstrated that calcium can modulate stilbene biosynthesis in Vitis, in mechanisms that require the involvement of calcium-dependent and mitogen-activated protein kinases (Aleynova et al., 2015; Jiao et al., 2017). Few studies on Arabidopsis, strawberry and grape also suggested a link between calcium and anthocyanins, where $\mathrm{Ca}^{2+}$, calmodulin, sugars, and protein kinases/phosphatases are key players, possibly by modulating anthocyanin biosynthetic genes (Vitrac et al., 2000; Shin et al., 2013; Xu et al., 2014; Peng et al., 2016; Zou et al., 2017). Minimal calcium levels are necessary for anthocyanin biosynthesis in carrot cells, in a mechanism that involves increased $\mathrm{Ca}^{2+}$-ATPase activity (Sudha and Ravishankar, 2003). In grape cells, a steady upregulation of DFR expression by increasing $\mathrm{CaCl}_{2}$ levels up to $100 \mathrm{mM}$ was demonstrated (Gollop et al., 2002). Accordingly, in the present study, the expression of the anthocyanin biosynthetic genes $V v D F R$ and $V v U F G T$, and the anthocyanin transporters $V v A M 1$ and $V v A B C C 1$ was enhanced upon treatment with calcium alone. However, this response was not observed when ABA or MeJA were also present, the combination of MeJA $+\mathrm{Ca}^{2+}$ causing a great downregulatory effect. Despite these results, post-translational regulation mechanisms prevailed, as calcium triggered a sharp inhibition in UFGT enzyme activity, likely explaining the decreased total anthocyanin content in grape cells and consequent lower pigmentation. This reduction in anthocyanin production and accumulation may greatly account for the decreased content in total phenolics observed in these cells. The repressive trend on $V v U F G T$ and $V v A B C C 1$ expression was also observed in intact detached grape berries treated in vitro, although total anthocyanin content was ultimately not affected. This result may be explained as whole fruits consist of a much more complex system, with interference of intrinsic levels of calcium, hormones and other solutes. Nonetheless, the effects observed on gene expression confirmed that calcium may have a great influence on berry secondary metabolism. Overall, results demonstrated that calcium can block anthocyanin biosynthesis by inhibiting UFGT at transcriptional and enzyme activity levels, and by downregulating transport genes involved in anthocyanin storage and stabilization in grape vacuoles (Gomez et al., 2009; Francisco et al., 2013). Other genes and enzyme isoforms likely play a role in these processes, and their combined actions ultimately determine the outcomes of 
A
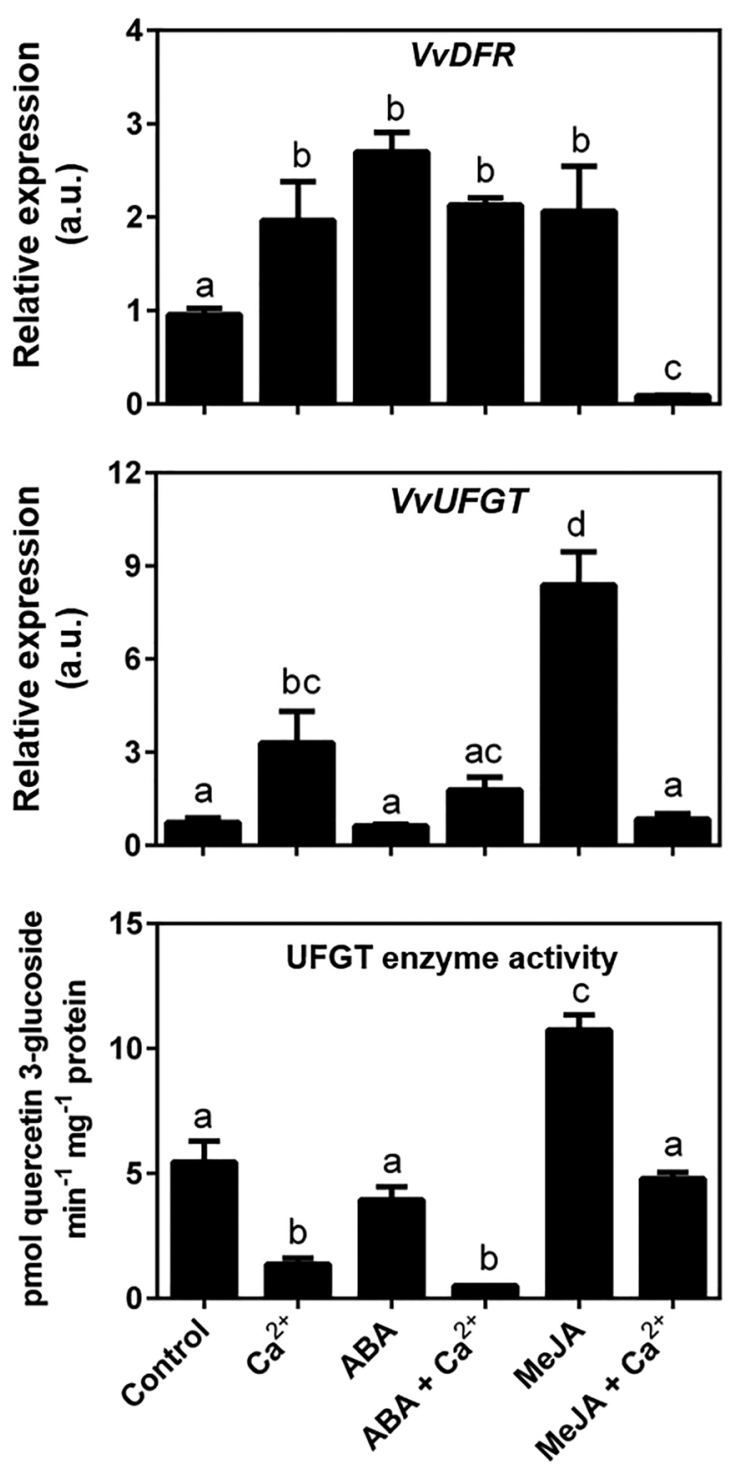

B
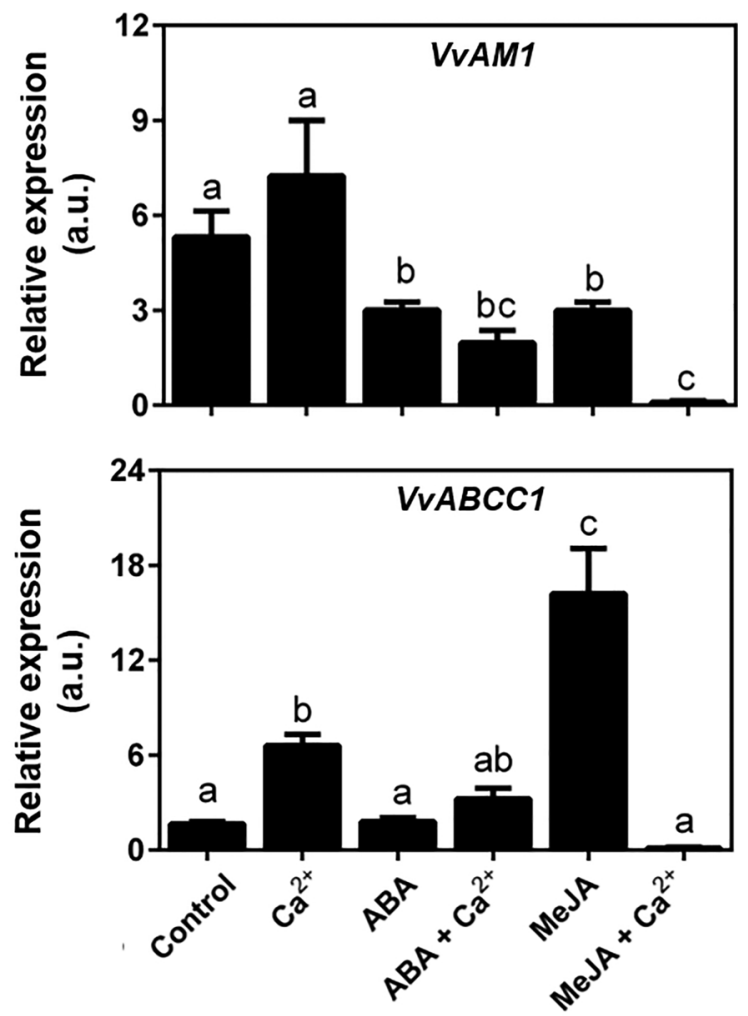

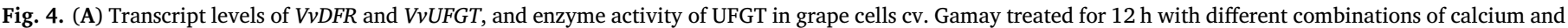

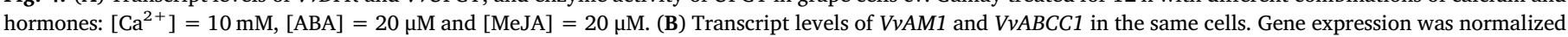

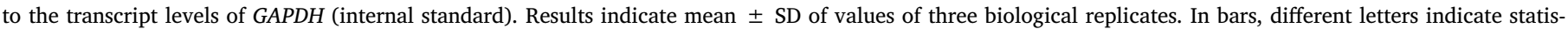
tically significant differences.

calcium action on phenolic content.

\subsection{Calcium regulates the expression and activity of cell wall enzymes involved in pectin organization}

In parallel to these effects, calcium also exerted significant regulation of the expression and activity of cell wall enzymes involved in pectin metabolism, as summarized in Fig. 7. The expression and activity of PG was consistently inhibited by calcium in grape cell cultures, and this effect was also frequently observed in whole fruits, demonstrating that this enzyme is extremely susceptible to calcium action. These results are in accordance to the competition of PG and calcium for binding pectic polysaccharides, that can either be degraded by PG or cross-linked by calcium. In addition, calcium can directly inhibit PG by competing with the substrate binding site, or by interacting with the substrate itself making it unavailable for the enzyme (Martins et al., 2012). These mechanisms are in line with ripening processes in fleshy fruits where calcium is required to inhibit premature softening (Wills and Rigney, 1980); green grape berries accumulate high levels of calcium and thus are strong and hard, however, as ripening progresses, a rise in PG activity occurs together with the cease on calcium flow to the fruits, in most cultivars, loosening the cell walls and promoting loss of cell cohesion, thus resulting in fruit softening (Martins et al., 2012). Interestingly, $V v P G 1$ was only expressed in the presence of ABA (either fed to cell cultures, or intrinsically present in berries), in line with previous studies reporting its marked increase during veraison and close correlation with berry softening and maturation (DeytieuxBelleau et al., 2008), where ABA has a major role by participating directly in the cell wall catabolism via the upregulation of the expression of a suite of important genes including PGs (Conde et al., 2007; Sun et al., 2012). In contrast to VvPG1, VvPG2 starts accumulating before veraison and its expression is kept at low levels during skin ripening, possibly being involved in triggering the ripening process (DeytieuxBelleau et al., 2008). The downregulation of VvPG2 by MeJA is in line with studies in tomato fruits demonstrating that MeJA may stimulate PG degradation (Saniewski et al., 1987). The effects of calcium on PME were not so linear, which could be explained by the fact that PME first acts on the de-esterification of polygalacturonans, and only then these 
A
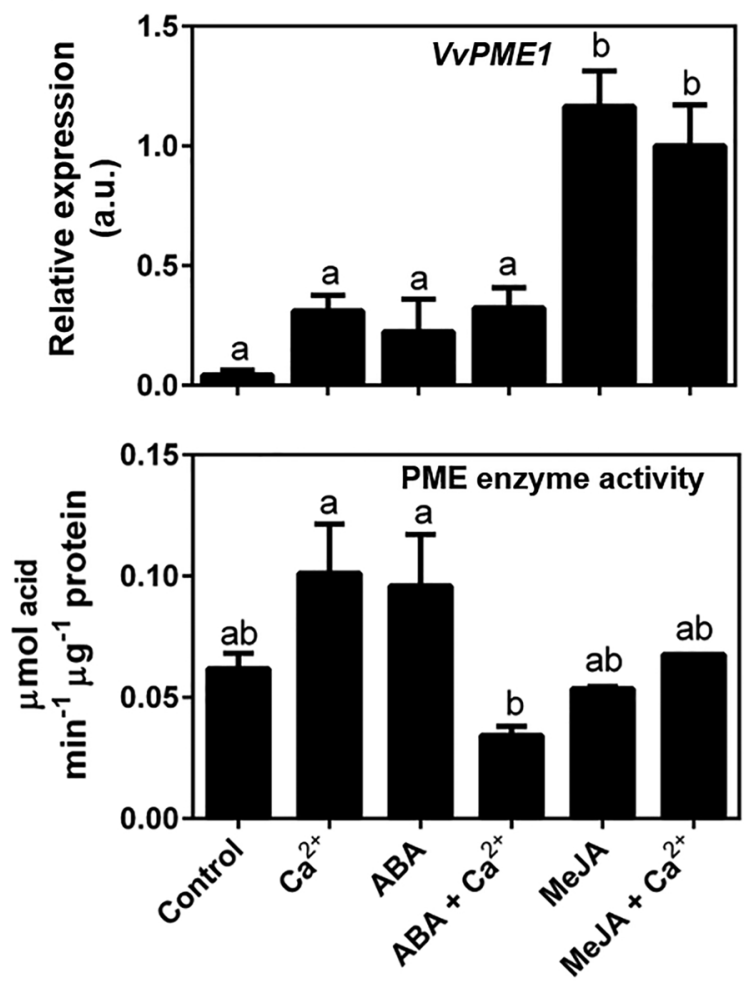

B
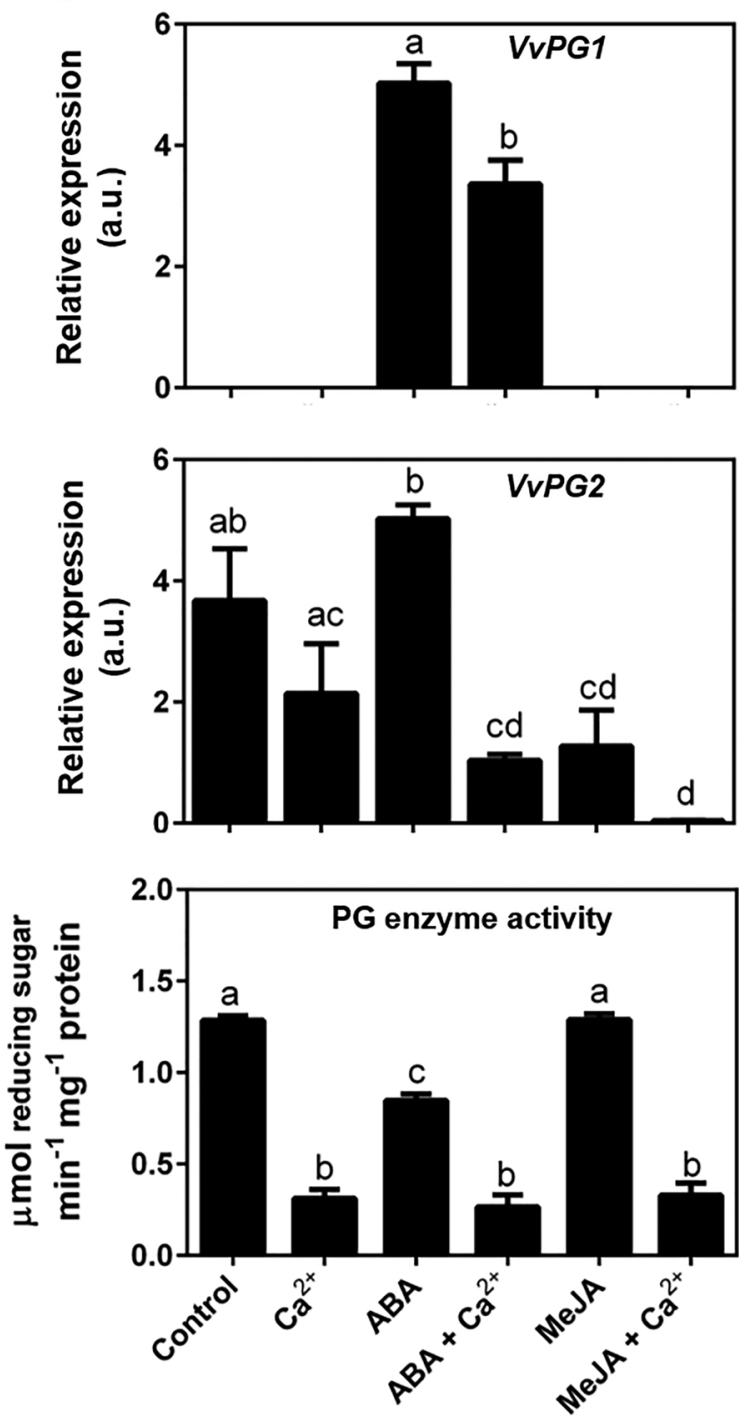

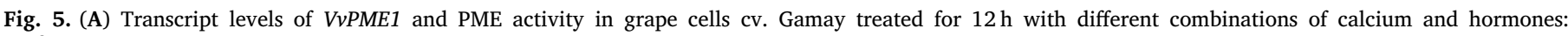

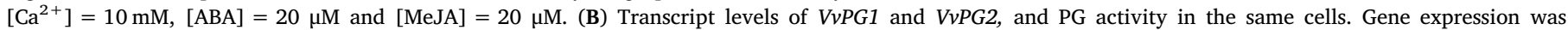

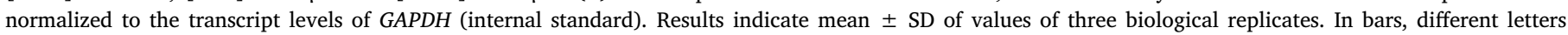
indicate statistically significant differences.

become available for cross-linking with calcium or degradation by PG (Hocking et al., 2016). Hence, a feedback regulatory mechanism may not occur in this step. Nonetheless, as in berries treated with MeJA $V v P M E 1$ was strongly downregulated by calcium, perhaps a regulatory mechanism arises from the calcium-MeJA link, as reported previously for other enzymes in this study. Furthermore, as enzyme activity decreased in cell cultures treated with ABA, a calcium-ABA link may also be apparent. Hence, different isoforms of PME could be expressed at specific stages of development, each having specific functions and regulatory modes (Barnavon et al., 2001).

\section{Conclusion}

The present study exposed the strong interplay between calcium and the phytohormones ABA and MeJA in modulating the major pathways involved in secondary metabolism and pectin cross-linking in grape berry cells, at gene expression, enzyme activity and metabolite levels, with emphasis on anthocyanin biosynthesis and accumulation. Studies involving the exogenous application of calcium sprays in the field, which are in progress, will allow the characterization of these effects on the overall solute composition and physical properties of grape berries, including color quality, cell wall structure, fruit firmness, and the consequences for berry microbiome and wine aroma.

\section{Author contribution statement}

VM and HG raised the hypothesis underlying this work and designed the experiments. VM, AG and CC carried out the experiments, performed data processing and statistical analysis. VM, AG, MS and HG wrote the article. VM and HG directed the study. All authors read and approved the manuscript.

\section{Funding}

This work was supported by European investment funds by FEDER/ COMPETE/POCI-Operacional Competitiveness and Internationalization Programme, under the Projects INTERACT-NORTE-01-0145-FEDER000017-Linha VitalityWine-ON 0013 and POCI-01-0145-FEDER006958, and by National Funds by FCT-Portuguese Foundation for Science and Technology, under the project UID/AGR/04033/2013, and 

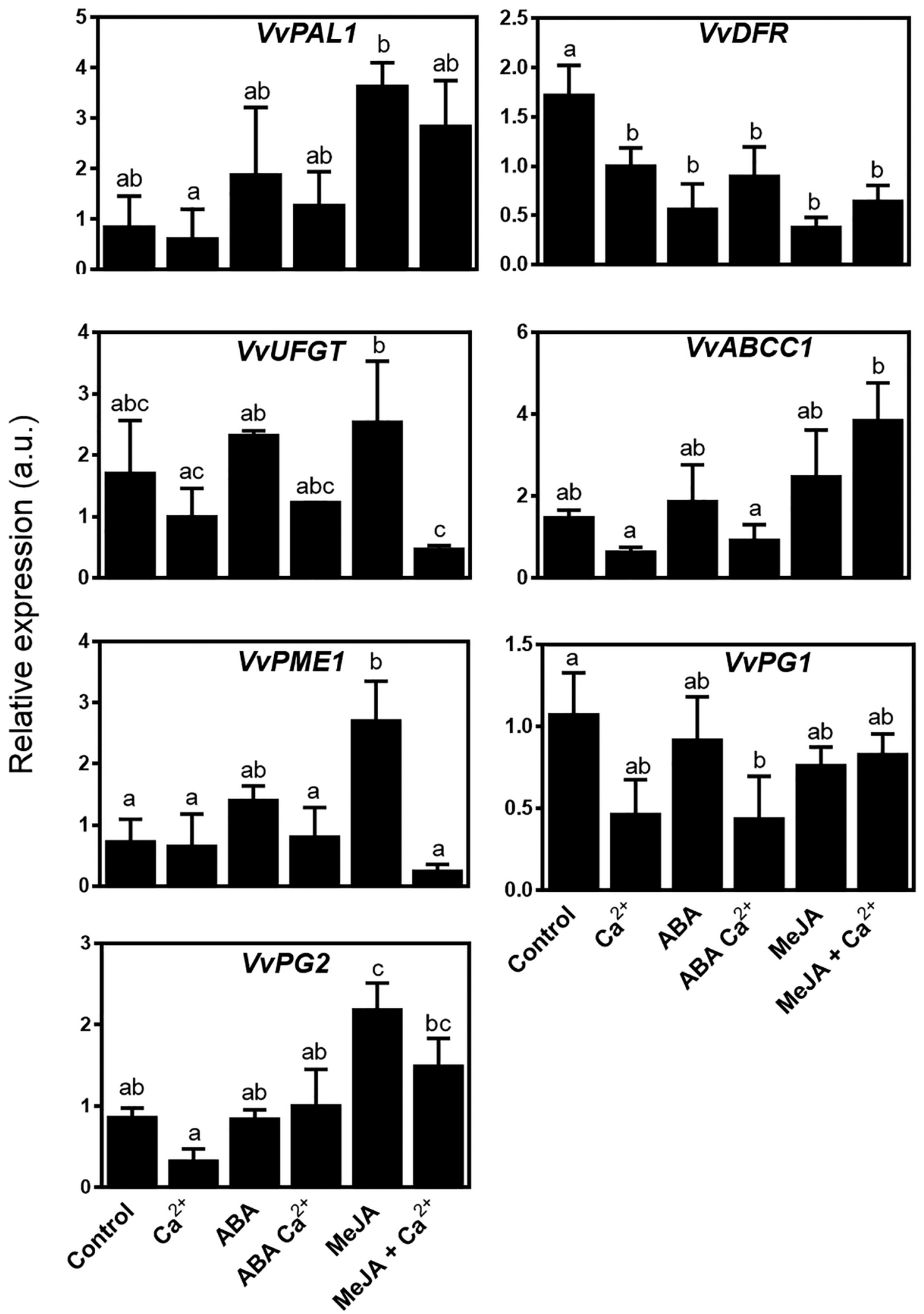

Fig. 6. Transcript levels of key genes in detached grape berries at veraison stage incubated for $4 \mathrm{~d}$ in mineral medium supplemented with different combinations of calcium and hormones: $\left[\mathrm{Ca}^{2+}\right]=10 \mathrm{mM},[\mathrm{ABA}]=20 \mu \mathrm{M}$ and $[\mathrm{MeJA}]=20 \mu \mathrm{M}$. Expression levels were normalized to the transcript levels of GAPDH (internal standard). Results are expressed as mean \pm SD and different letters indicate statistically significant differences. 


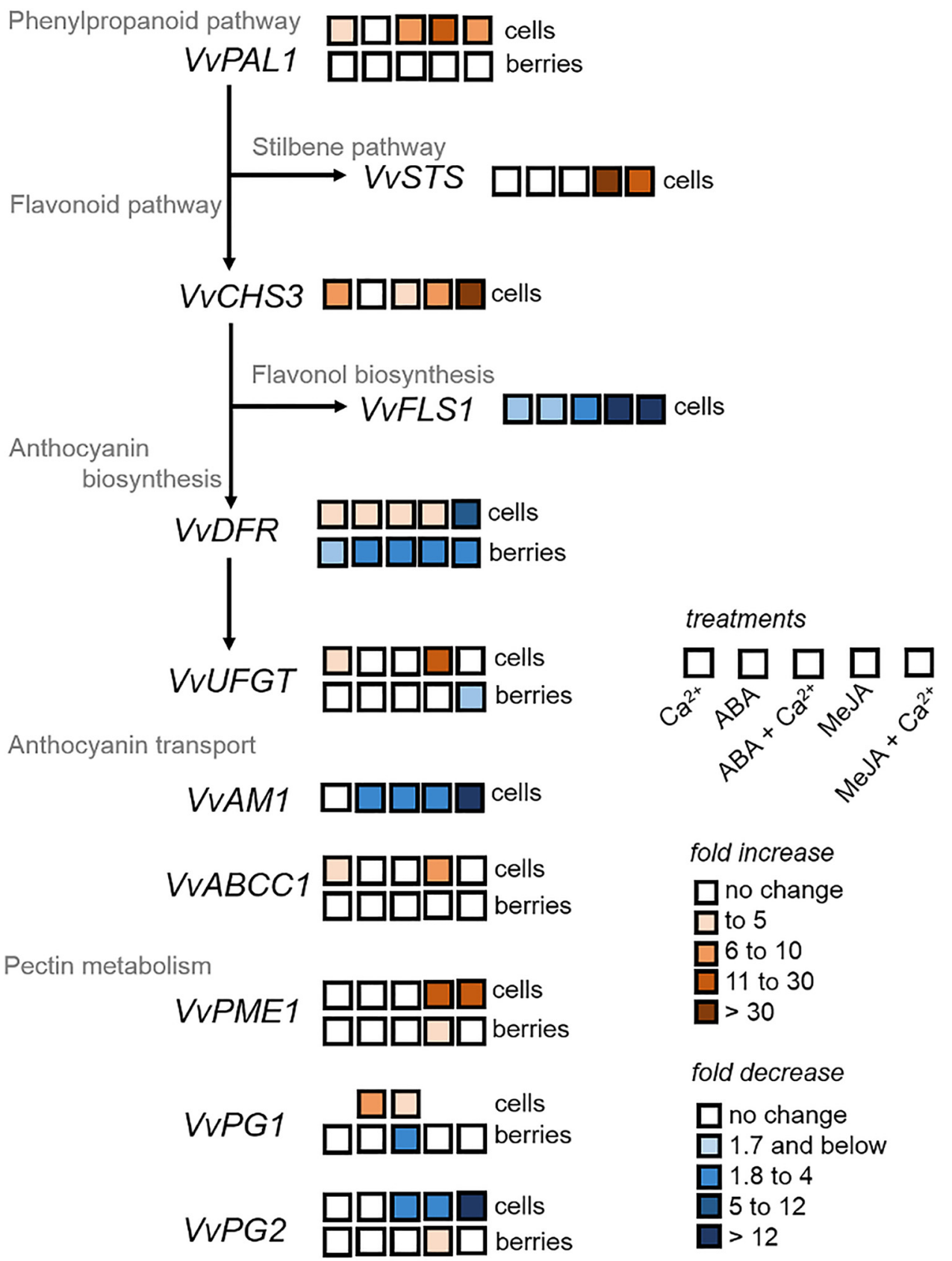

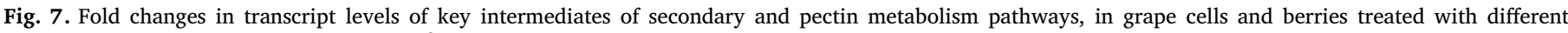

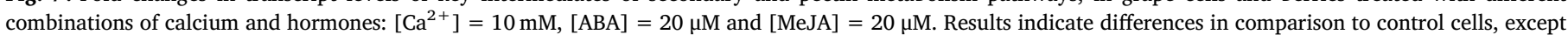
for $V v P G 1$ in cell suspensions where transcripts were only detected in the presence of ABA.

CherryCrackLess (PTDC/AGR-PRO/7028/2014). VM was supported by a FCT postdoctoral Grant (SFRH/BPD/107905/2015).

\section{Declarations of interest}

None.

\section{Acknowledgement}

The authors thank Professor Serge Delrot (University of Bordeaux, France) for providing the grape cell line Gamay Fréaux var. Teinturier.

\section{Appendix A. Supplementary data}

Supplementary material related to this article can be found, in the online version, at doi:https://doi.org/10.1016/j.jplph.2018.08.011.

\section{References}

Aleynova, O.A., Dubrovina, A.S., Manyakhin, A.Y., Karetin, Y.A., Kiselev, K.V., 2015. Regulation of resveratrol production in Vitis amurensis cell cultures by calcium-dependent protein kinases. Appl. Biochem. Biotechnol. 175 (3), 1460-1476.

Barnavon, L., Doco, T , Terrier, N., Ageorges, A., Romieu, C., Pellerin, P. 2001. Involvement of pectin methyl-esterase during the ripening of grape berries: partial cDNA isolation, transcript expression and changes in the degree of methyl-esterification of cell wall pectins. Phytochemistry 58 (5), 693-701.

Bonomelli, C., Ruiz, R., 2010. Effects of foliar and soil calcium application on yield and quality of table grape cv.'Thompson Seedless'. J. Plant Nutr. 33 (3), 299-314.

Bradford, M.M., 1976. A rapid and sensitive method for the quantitation of microgram quantities of protein utilizing the principle of protein-dye binding. Anal. Biochem. 72 (1-2), 248-254.

Conde, C., Silva, P., Fontes, N., Dias, A.C.P., Tavares, R.M., Sousa, M.J., Agasse, A., Delrot, S., Gerós, H., 2007. Biochemical changes throughout grape berry development and 
fruit and wine quality. Food 1, 1-22.

Conde, A., Pimentel, D., Neves, A., Dinis, L.T., Bernardo, S., Correia, C.M., Gerós, H., Moutinho-Pereira, J., 2016. Kaolin foliar application has a stimulatory effect on phenylpropanoid and flavonoid pathways in grape berries. Front. Plant Sci. 7, 1150.

Coombe, B.G., 1995. Growth stages of the grapevine: adoption of a system for identifying grapevine growth stages. Aust. J. Grape Wine Res. 1 (2), 104-110.

Dai, Z.W., Meddar, M., Renaud, C., Merlin, I., Hilbert, G., Delrot, S., Gomès, E., 2014. Long-term in vitro culture of grape berries and its application to assess the effects of sugar supply on anthocyanin accumulation. J. Exp. Bot. 65 (16), 4665-4677.

Decendit, A., Merillon, J.M., 1996. Condensed tannin and anthocyanin production in Vitis vinifera cell suspension cultures. Plant Cell Rep. 15 (10), 762-765.

Deytieux-Belleau, C., Vallet, A., Donèche, B., Geny, L., 2008. Pectin methylesterase and polygalacturonase in the developing grape skin. Plant Physiol. Biochem. 46 (7), 638-646.

Dodd, A.N., Kudla, J., Sanders, D., 2010. The language of calcium signaling. Annu. Rev. Plant Biol. 61, 593-620.

Fontes, N., Silva, R., Vignault, C., Lecourieux, F., Gerós, H., Delrot, S., 2010. Purification and functional characterization of protoplasts and intact vacuoles from grape cells. BMC Res. Notes 3 (1), 19.

Fortes, A.M., Teixeira, R.T., Agudelo-Romero, P., 2015. Complex interplay of hormonal signals during grape berry ripening. Molecules 20 (5), 9326-9343.

Francisco, R.M., Regalado, A., Ageorges, A., Burla, B.J., Bassin, B., Eisenach, C., Zarrouk, O., Vialet, S., Marlin, T., Chaves, M.M., Martinoia, E., 2013. ABCC1, an ATP binding cassette protein from grape berry, transports anthocyanidin 3-O-glucosides. Plant Cell 25 (5), 1840-1854

Gainza-Cortés, F., Pérez-Dïaz, R., Pérez-Castro, R., Tapia, J., Casaretto, J.A., González, S., Peña-Cortés, H., Ruiz-Lara, S., González, E., 2012. Characterization of a putative grapevine Zn transporter, VvZIP3, suggests its involvement in early reproductive development in Vitis vinifera L. BMC Plant Biol. 12 (1), 111.

Gollop, R., Even, S., Colova-Tsolova, V., Perl, A., 2002. Expression of the grape dihydroflavonol reductase gene and analysis of its promoter region. J. Exp. Bot. 53 (373), 1397-1409.

Gomez, C., Terrier, N., Torregrosa, L., Vialet, S., Fournier-Level, A., Verries, C., Souquet, J.M., Mazauric, J.P., Klein, M., Cheynier, V., Ageorges, A, 2009. Grapevine MATEtype proteins act as vacuolar $\mathrm{H}^{+}$-dependent acylated anthocyanin transporters. Plant Physiol. 150 (1), 402-415.

Hagerman, A.E., Austin, P.J., 1986. Continuous spectrophotometric assay for plant pectin methyl esterase. J. Agric. Food Chem. 34 (3), 440-444.

Hamilton, D.W., Hills, A., Köhler, B., Blatt, M.R., 2000. $\mathrm{Ca}^{2+}$ channels at the plasma membrane of stomatal guard cells are activated by hyperpolarization and abscisic acid. Proc. Natl. Acad. Sci. 97 (9), 4967-4972.

Hocking, B., Tyerman, S.D., Burton, R.A., Gilliham, M., 2016. Fruit calcium: transport and physiology. Front. Plant Sci. 7, 569.

Hopkirk, G., Harker, F.R., Harman, J.E., 1990. Calcium and the firmness of kiwifruit. N. Z. J. Crop Hortic. Sci. 18 (4), 215-219.

Hu, X., Wansha, L., Chen, Q., Yang, Y., 2009. Early signals transduction linking the synthesis of jasmonic acid in plant. Plant Signal. Behav. 4 (8), 696-697.

Jiao, Y., Wang, D., Wang, L., Jiang, C., Wang, Y., 2017. VqMAPKKK38 is essential for stilbene accumulation in grapevine. Hortic. Res. 4, 17058.

Ladyzhenskaia, E.P., Korableva, N.P., 2008. Effect of jasmonic acid on $\mathrm{Ca}^{2+}$ transport through the plasmalemma of potato tuber cells. Prikl. Biokhim. Mikrobiol. 44 (6), 709-713.

Larronde, F., Krisa, S., Decendit, A., Cheze, C., Deffieux, G., Mérillon, J.M., 1998. Regulation of polyphenol production in Vitis vinifera cell suspension cultures by sugars. Plant Cell Rep. 17 (12), 946-950.

Lohani, S., Trivedi, P.K., Nath, P., 2004. Changes in activities of cell wall hydrolases during ethylene-induced ripening in banana: effect of 1-MCP, ABA and IAA. Postharvest Biol. Technol. 31 (2), 119-126.

Madani, B., Mirshekari, A., Sofo, A., Tengku Muda Mohamed, M., 2016. Preharvest calcium applications improve postharvest quality of papaya fruits (Carica papaya L. Cv. Eksotika II). J. Plant Nutr. 39 (10), 1483-1492.

Martín-Diana, A.B., Rico, D., Frias, J.M., Barat, J.M., Henehan, G.T.M., Barry-Ryan, C, 2007. Calcium for extending the shelf life of fresh whole and minimally processed fruits and vegetables: a review. Trends Food Sci. Technol. 18 (4), 210-218.

Martins, V., Cunha, A., Gerós, H., Hanana, M., Blumwald, E., 2012. Mineral compounds in grape berry. In: Gerós, H., Chaves, M.-M., Delrot, S. (Eds.), The Biochemistry of the Grape Berry. Bentham Science Publishers, pp. 23-43.

Martins, V., Teixeira, A., Bassil, E., Blumwald, E., Gerós, H., 2014a. Metabolic changes of Vitis vinifera berries and leaves exposed to Bordeaux mixture. Plant Physiol. Biochem. $82,270-278$.
Martins, V., Teixeira, A., Bassil, E., Hanana, M., Blumwald, E., Gerós, H., 2014b. Copper-based fungicide Bordeaux mixture regulates the expression of Vitis vinifera copper transporters. Aust. J. Grape Wine Res. 20 (3), 451-458.

Martins, V., Teixeira, A., Gerós, H., 2015. Changes in the volatile composition of wine from grapes treated with Bordeaux mixture: a laboratory-scale study. Aust. J. Grape Wine Res. 21 (3), 425-429.

Martins, V., Carneiro, F., Conde, C., Sottomayor, M., Gerós, H., 2017. The grapevine VvCAX3 is a cation/ $/ \mathrm{H}^{+}$exchanger involved in vacuolar $\mathrm{Ca}^{2+}$ homeostasis. Planta 246 (6), 1083-1096.

Mori, K., Sugaya, S., Gemma, H., 2005. Decreased anthocyanin biosynthesis in grape berries grown under elevated night temperature condition. Sci. Hortic. 105 (3), 319-330.

Nicoue, E.E., Savard, S., Belkacemi, K., 2007. Anthocyanins in wild blueberries of Quebec: extraction and identification. J. Agric. Food Chem. 55 (14), 5626-5635.

Noronha, H., Conde, C., Delrot, S., Gerós, H., 2015. Identification and functional characterization of grapevine transporters that mediate glucose-6-phosphate uptake into plastids. Planta 242 (4), 909-920.

Pei, Z.M., Murata, Y., Benning, G., Thomine, S., Klüsener, B., Allen, G.J., Grill, E. Schroeder, J.I., 2000. Calcium channels activated by hydrogen peroxide mediate abscisic acid signalling in guard cells. Nature 406 (6797), 731.

Peng, H., Yang, T., Whitaker, B.D., Shangguan, L., Fang, J., 2016. Calcium/calmodulin alleviates substrate inhibition in a strawberry UDP-glucosyltransferase involved in fruit anthocyanin biosynthesis. BMC Plant Biol. 16 (1), 197.

Reid, K.E., Olsson, N., Schlosser, J., Peng, F., Lund, S.T., 2006. An optimized grapevine RNA isolation procedure and statistical determination of reference genes for real-time RT-PCR during berry development. BMC Plant Biol. 6 (1), 27.

Saniewski, M., Urbanek, H., Czapski, J., 1987. Effects of methyl jasmonate on ethylene production, chlorophyll degradation, and polygalacturonase activity in tomatoes. J. Plant Physiol. 127 (1-2), 177-181.

Shin, D.H., Choi, M.G., Lee, H.K., Cho, M., Choi, S.B., Choi, G., Park, Y.I., 2013. Calcium dependent sucrose uptake links sugar signaling to anthocyanin biosynthesis in Arabidopsis. Biochem. Biophys. Res. Commun. 430 (2), 634-639.

Siddiqui, S., Bangerth, F., 1995. Effect of pre-harvest application of calcium on flesh firmness and cell-wall composition of apples-influence of fruit size. J. Hortic. Sci. 70 (2), 263-269.

Sudha, G., Ravishankar, G.A., 2003. The role of calcium channels in anthocyanin production in callus cultures of Daucus carota. Plant Growth Regul. 40 (2), 163-169.

Suhita, D., Kolla, V.A., Vavasseur, A., Raghavendra, A.S., 2003. Different signaling pathways involved during the suppression of stomatal opening by methyl jasmonate or abscisic acid. Plant Sci. 164 (4), 481-488.

Suhita, D., Raghavendra, A.S., Kwak, J.M., Vavasseur, A., 2004. Cytoplasmic alkalization precedes reactive oxygen species production during methyl jasmonate-and abscisic acid-induced stomatal closure. Plant Physiol. 134 (4), 1536-1545.

Sun, Q.P., Guo, Y., Sun, Y., Sun, D.Y., Wang, X.J., 2006. Influx of extracellular $\mathrm{Ca}^{2+}$ involved in jasmonic-acid-induced elevation of $\left[\mathrm{Ca}^{2+}\right]$ cyt and JR1 expression in Arabidopsis thaliana. J. Plant Res. 119 (4), 343-350.

Sun, L., Sun, Y., Zhang, M., Wang, L., Ren, J., Cui, M., Wang, Y., Ji, K., Li, P., Li, Q., Chen, P., 2012. Suppression of 9-cis-epoxycarotenoid dioxygenase, which encodes a key enzyme in abscisic acid biosynthesis, alters fruit texture in transgenic tomato. Plant Physiol. 158 (1), 283-298.

Taylor, S.L., 1993. Why sulfite alternatives. Food Technol. 47, 14

Vitrac, X., Larronde, F., Krisa, S., Decendit, A., Deffieux, G., Mérillon, J.M., 2000. Sugar sensing and $\mathrm{Ca}^{2+}$-calmodulin requirement in Vitis vinifera cells producing anthocyanins. Phytochemistry 53 (6), 659-665.

Wasternack, C., Hause, B., 2002. Jasmonates and octadecanoids: signals in plant stress responses and development. Prog. Nucleic Acid Res. Mol. Biol. 72, 165-221.

Waterhouse, A.L., 2002. Determination of Total Phenolics. Curr. Protoc. Food Anal. Chem. I.1.1.1-I1.1.8.

Wills, R.B.H., Rigney, C.J., 1980. Effect of calcium on activity of mitochondria and pectic enzymes isolated from tomato fruits. J. Food Biochem. 3 (2-3), 103-110.

Wójcik, P., Akgül, H., Demirtaş, İ., Sarısu, C., Aksu, M., Gubbuk, H., 2013. Effect of preharvest sprays of calcium chloride and sucrose on cracking and quality of 'Burlat' sweet cherry fruit. J. Plant Nutr. 36 (9), 1453-1465.

Xu, W., Peng, H., Yang, T., Whitaker, B., Huang, L., Sun, J., Chen, P., 2014. Effect of calcium on strawberry fruit flavonoid pathway gene expression and anthocyanin accumulation. Plant Physiol. Biochem. 82, 289-298.

Zou, B., Wan, D., Li, R., Han, X., Li, G., Wang, R., 2017. Calmodulin-binding protein CBP60g functions as a negative regulator in Arabidopsis anthocyanin accumulation. PLoS One 12 (3), e0173129. 